\title{
Measuring Impact in Stereotactic and Functional Neurosurgery: An Analysis of the Top 100 Most Highly Cited Works and the Citation Classics in the Field
}

\author{
Nir Lipsman Andres M. Lozano \\ Division of Neurosurgery, Toronto Western Hospital, University of Toronto, Toronto, Ont., Canada
}

\section{Key Words}

Functional neurosurgery $\cdot$ Top 100 papers $\cdot$ Citation

classics $\cdot$ Literature search $\cdot$ Citation indices

\begin{abstract}
Background: Functional neurosurgery is a rapidly expanding field, with an exponentially growing literature. However, as with other fields, it can sometimes be difficult to distinguish between what is incremental and what is transformational. One way of measuring durable impact is examining the number of times a specific piece of scholarship is cited by others in the field. For example, papers that have been cited at least 400 times are designated 'citation classics' or works that, by virtue of very high citations, have been deemed of particular importance by researchers working in related disciplines. Methods: We queried a large, web-based scholarly database using 49 pre-selected search terms. The results for each individual query was manually examined for relevance to the functional neurosurgery field in order to arrive at the top 100 most highly cited papers as well as the citation classics. Results: The top 100 most cited papers, including 61 citation classics, in the stereotactic and functional neurosurgery field can be divided into 7 categories: functional/anatomic studies, technological innovations, and
\end{abstract}

papers relevant to movement disorders, pain, psychiatry, radiosurgery and epilepsy. Conclusions: We have attempted to ascertain which papers have had, and continue to have, significant impact in our rapidly advancing field. At a minimum, the citation classics in functional neurosurgery provide both trainees and seasoned surgeons with a reading list of the 'must-know' works in the field - works whose influence have helped shape the direction of functional neurosurgery well into the future.

Copyright $\odot 2012$ S. Karger AG, Basel

\section{Background}

Technological and conceptual advances in functional neurosurgery have led to a rapidly growing biomedical literature. Given the diversity of diagnoses and number of procedures under the umbrella of 'functional disorders', ranging from movement disorders to psychiatry to radiosurgery, it can often be difficult to keep up and distinguish

No external funding was used to design or analyze this study. A.M.L. is a Canada Research Chair Tier I in Neuroscience and a consultant for Medtronic, St. Jude, Eli Lilly and Boston Scientific. N.L. has nothing to disclose.

\section{KARGER}

Fax +4161306 1234

E-Mail karger@karger.ch

www.karger.com (c) 2012 S. Karger AG, Basel

1011-6125/12/0903-0201\$38.00/0

Accessible online at:

www.karger.com/sfn
Andres M. Lozano

Division of Neurosurgery

Toronto Western Hospital, 399 Bathurst St., 4W-431

Toronto, ON M5T2S8 (Canada)

Tel.+1 416603 6200,E-Mail lozano@uhnresearch.ca 
Table 1. Search terms used

\begin{tabular}{lll}
\hline Balloon compression & Glycerol & Proton Beam \\
Brachytherapy & Hemispherectomy & Radiofrequency \\
Brain-machine interface & Image guidance & Radiosurgery \\
Brain stimulation & Image-guided surgery & Rhizotomy \\
Callosotomy & Intrathecal & Spinal cord stimulation \\
Capsulotomy & Language mapping & Stereotactic \\
Cingulotomy & Linac & Stereotaxic \\
Cordotomy & Lobectomy & Stereotaxis \\
CyberKnife & Localization & Subpial transection \\
Deep brain stimulation & Mapping & Subthalamotomy \\
Dorsal root entry zone & Mesencephalotomy & Sympathectomy \\
DREZ & Microvascular decompression & Temporal lobectomy \\
Electrical stimulation & Motor cortex stimulation & Thalamotomy \\
Epidural stimulation & Movement disorder surgery & Tractotomy \\
Fetal transplantation & Neuronavigation & Vagal nerve \\
Gamma Knife & Pallidotomy & \\
Gene transfer & Peripheral nerve stimulation & \\
\hline
\end{tabular}

between the important and the incremental developments in the field. One way of doing so is examining which publications have been cited most frequently by others within the field and its related disciplines. Whether having a positive impact or a negative one, highly cited works can be viewed, when analyzed as a whole, as an objectively agreed-upon list of work that has influenced the field, given their recognition by others. In bibliometric terms, a citation classic is defined as a work that has been cited at least 400 times by others in the biomedical literature $[1,2]$. An examination of citation classics in different fields and even within different diagnoses can yield an interesting snapshot of key papers in that area and provide unique insights into how impact is achieved and changes with time $[3,4]$. For example, we have previously shown that the field of Parkinson's disease (PD) contains approximately as many citation classics as the entire field of neurosurgery $[5,6]$. The field of major depression, on the other hand, contains more citation classics than both combined [7]. Such lists reflect not only the breadth of work within a field but also the relative impact of specific types of work in that area. An example is that papers that described scales and measures in depression accounted for 8 of the top 10 most highly cited papers in the field.

The list of highly cited papers is valuable for several reasons. Decisions regarding funding, resource allocation and academic priorities can be made by identifying which areas offer most promise and which do not. Citation classics also allow beginner and expert members of the field to keep up with the literature and identify, at a glance, which works have made a lasting impact.
Other papers have examined highly cited works in sub-disciplines within functional neurosurgery, such as radiosurgery $[8,9]$. For example, one group has recently analyzed citation and publication patterns specifically in the field of stereotaxy, with a focus on the contemporary era (work since 1993) [8]. The authors sought to describe global trends in stereotactic research and identify particularly prolific and productive surgical centers. Thus far, however, no work has examined the citation classics in the field of stereotactic and functional neurosurgery as a whole. The objective of this paper is to examine which papers in the functional neurosurgery literature have become citation classics and, further, to identify what are the 100 most highly cited works in the field.

\section{Methods}

For our literature search, we used a free, downloadable, publically available software (Harzing's Publish or Perish 3, PoP3) that utilizes Google Scholar to identify citation indices [10]. Google Scholar is an online search engine that crawls the Internet in search of publications in the biomedical literature, returning results with listed citations. Given the breadth and diversity of the functional neurosurgery field, we sought to be as inclusive as possible with our search criteria and search terms. Our inclusion criteria for papers and studies were the following: (i) functional neurosurgical procedures done in humans; (ii) in one of the main foci of interest of functional neurosurgery (pain, movement disorders, psychiatry, epilepsy and radiosurgery); (iii) discoveries that were made in the course of surgery for any of the preceding indications, and (iv) technology that was developed to facilitate any of the preceding functional neurosurgery procedures. 
We identified 49 search terms and searched for each individually anywhere in the paper, title or abstract (table 1). We then manually examined all search results for all search terms individually and gathered all papers with at least 300 citations, a number designed to include all citation classics as well as furnish the final list of the top 100 papers. We excluded (i) patents, books, manuals and non-biomedical publications; (ii) papers dealing with preclinical models and experimental (basic science) findings regardless of their relevance to functional neurosurgery, and (iii) literature reviews dealing with specific diagnoses.

\section{Results}

Using the above search terms, we identified 61 papers in the functional neurosurgery field with at least 400 citations, the so-called citation classics (table 2). Extending our citation cutoff to 300 , we were also able to identify the top 100 most highly cited works in the field (online suppl. table 1; for all online suppl. material, see www. karger.com/doi/10.1159/000337170). The 61 citation classics were found in 25 different journals, with 11 journals having at least 2 papers (table 3 ). In order to facilitate an analysis of the types of papers that are citation classics and of how trends may have evolved with time, we divided all our results into categories based on the predominant theme of each paper. There were 7 broad categories: functional/anatomic studies, technological advancements, movement disorders, pain, psychiatry, epilepsy and radiosurgery. Table 4 lists the categories, along with the number of citation classics and top 100 papers in each category.

\section{Functional/Anatomic Studies}

There were 12 citation classics and 27 top 100 papers in this category. These papers sought to uncover and explore basic functions of central nervous system structures in the course of a functional neurosurgical procedure, or as a consequence of such a procedure. As these types of papers can have broad applicability and relevance to multiple disciplines, from neurology to neurophysiology, they are frequently the most highly cited works, and also some of the oldest papers in the literature. For example, the top 3 papers in the functional neurosurgery field were all in this category. These 3 papers alone account for $47 \%$ of all the citations in the top 10. This is likely a function of the early days of the field, where new procedures and their consequences were being developed and explored. Indeed, the oldest paper in the top 100, published in 1937, was an examination of somatic and motor sensation induced by open electrical stimulation [11].

Highly Cited Works in Functional Neurosurgery

\section{Technology}

There were 7 citation classics and 12 top 100 papers in the technology category. Here, we included papers that described new techniques, procedures or equipment with the specific aim of advancing either diagnosis or treatment in functional neurosurgery. As technology is intimately related to the field, it can be difficult to tease out which papers represent technological, as opposed to clinical, advances, and to define where this line should be drawn, if it should be drawn at all. The Limitations section below discusses this in detail. We observed, however, that the most significant advances prior to 1980 were the development of radiosurgery by Leksell in 1951 and the introduction of the stereotactic frame by Spiegel and Wycis in 1947, both fundamental components of modern practice. More recent technological advances have focused on image guidance, the integration of stereotaxy into clinical practice and on interfacing the brain with a machine. Indeed, one of the more impressive and informative results was that a paper dealing with neuronal control of a prosthetic arm in a human, published in 2006, had garnered nearly 1,000 citations in 5 years, suggesting a building momentum in the brain-machine interface field.

\section{Movement Disorders}

This field represents, in many ways, the cornerstone of modern functional neurosurgery. There were 31 top 100 papers in the functional neurosurgery literature related to movement disorders, and of these 22 were citation classics, representing the largest proportion of all the categories. Among the citation classics, work relevant to PD made up the vast majority (19 publications), with the remaining 3 works focusing on tremor. Interestingly, in the top 4 works were papers related to each of the areas fetal cell transplantation, stimulation and lesioning, reflecting the diversity of different approaches to PD in the field. Among the 31 top 100 papers, $6(20 \%)$ dealt with lesioning, 12 (38.7\%) dealt with stimulation, 1 (3.3\%) compared lesioning to stimulation, and 12 (40\%) dealt with cell transplantation, including the most highly cited work dealing with movement disorders in the list. For the citation classics, these numbers were $3(10 \%)$ for lesions, 10 (33\%) for stimulation, 1 (3.3\%) for both, and 8 (26.7\%) for transplantation. Put differently, papers examining stimulation had more citation classics, although papers dealing with cell transplantation had a slightly higher representation in the top 100 .

\section{Pain}

Papers dealing with pain neurosurgery accounted for 12 of the top 100 papers, of which 8 were citation classics.

Stereotact Funct Neurosurg 2012;90:201-209 
Table 2. The 61 citation classics

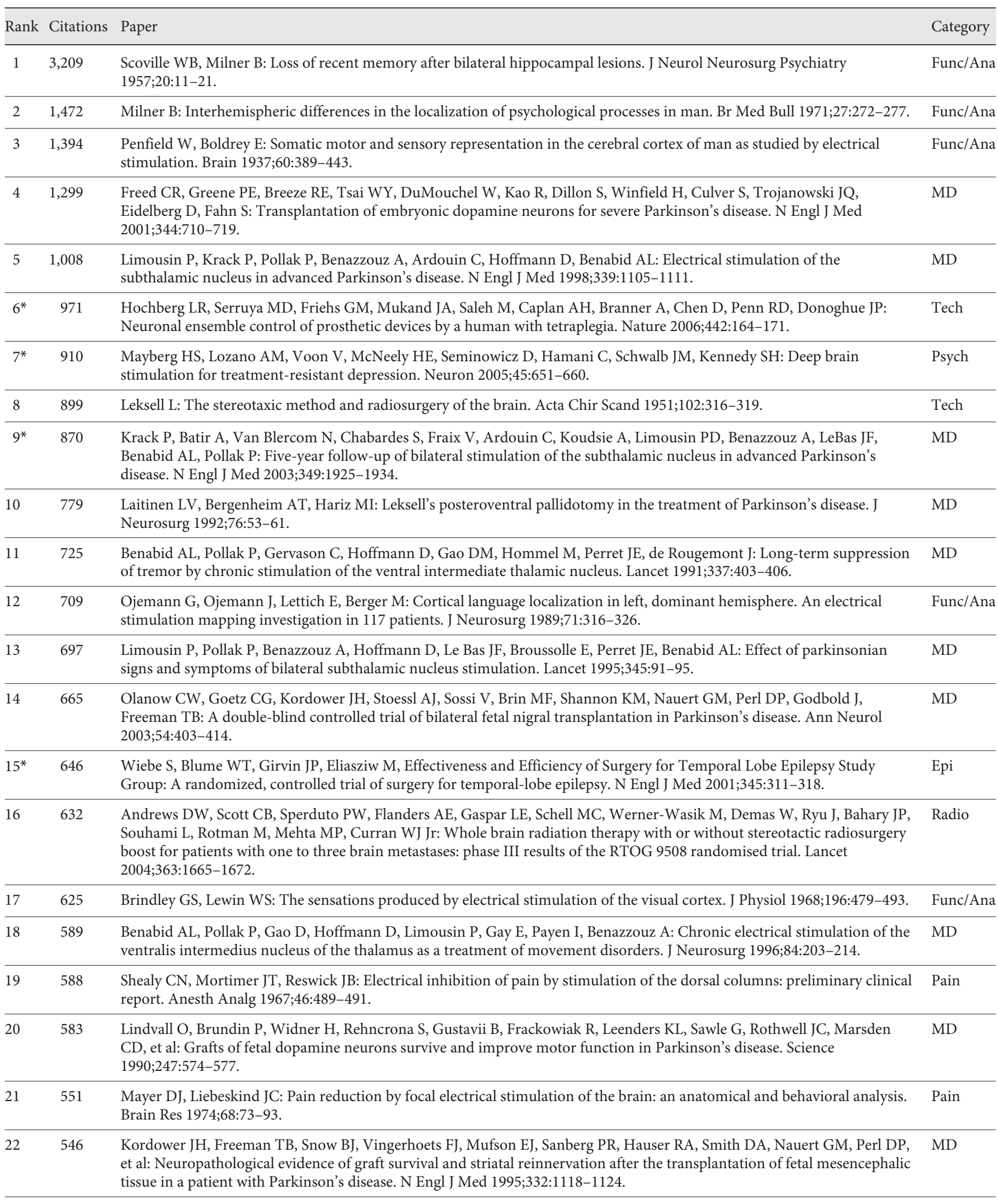


Table 2 (continued)

\begin{tabular}{|c|c|c|c|}
\hline Rank & Citations & Paper & Category \\
\hline 25 & 515 & $\begin{array}{l}\text { Flickinger JC, Kondziolka D, Lunsford LD, Coffey RJ, Goodman ML, Shaw EG, Hudgins WR, Weiner R, Harsh GR 4th, } \\
\text { Sneed PK, et al: A multi-institutional experience with stereotactic radiosurgery for solitary brain metastasis. Int J Radiat } \\
\text { Oncol Biol Phys 1994;28:797-802. }\end{array}$ & Radio \\
\hline 26 & 512 & Milner B: Visual recognition and recall after right temporal-lobe excision in man. Neuropsychologia 1968;6:191-209. & Func/Ana \\
\hline 27 & 511 & $\begin{array}{l}\text { Barker FG 2nd, Jannetta PJ, Bissonette DJ, Larkins MV, Jho HD: The long-term outcome of microvascular decompression } \\
\text { for trigeminal neuralgia. N Engl J Med 1996;334:1077-1083. }\end{array}$ & Pain \\
\hline 28 & 509 & $\begin{array}{l}\text { Spiegel EA, Wycis HT, Marks M, Lee AJ: Stereotaxic apparatus for operations on the human brain. Science 1947;106:349- } \\
350 .\end{array}$ & Tech \\
\hline 31 & 495 & Milner B: Psychological defects produced by temporal lobe excision. Res Publ Assoc Res Nerv Ment Dis 1958;36:244-257. & Func/Ana \\
\hline 32 & 482 & $\begin{array}{l}\text { Deuschl G, Schade-Brittinger C, Krack P, Volkmann J, Schäfer H, Bötzel K, Daniels C, Deutschländer A, Dillmann U, Eisner } \\
\text { W, Gruber D, Hamel W, Herzog J, Hilker R, Klebe S, Kloss M, Koy J, Krause M, Kupsch A, Lorenz D, Lorenzl S, Mehdorn } \\
\text { HM, Moringlane JR, Oertel W, Pinsker MO, Reichmann H, Reuss A, Schneider GH, Schnitzler A, Steude U, Sturm V, } \\
\text { Timmermann L, Tronnier V, Trottenberg T, Wojtecki L, Wolf E, Poewe W, Voges J, German Parkinson Study Group, } \\
\text { Neurostimulation Section: A randomized trial of deep-brain stimulation for Parkinson's disease. N Engl J Med } \\
\text { 2006;355:896-908. }\end{array}$ & $\mathrm{MD}$ \\
\hline 33 & 479 & $\begin{array}{l}\text { Roberts DW, Strohbehn JW, Hatch JF, Murray W, Kettenberger H: A frameless stereotaxic integration of computerized } \\
\text { tomographic imaging and the operating microscope. J Neurosurg 1986;65:545-549. }\end{array}$ & Tech \\
\hline 34 & 472 & $\begin{array}{l}\text { Schuurman PR, Bosch DA, Bossuyt PM, Bonsel GJ, van Someren EJ, de Bie RM, Merkus MP, Speelman JD: A comparison } \\
\text { of continuous thalamic stimulation and thalamotomy for suppression of severe tremor. N Engl J Med 2000;342:461-468. }\end{array}$ & $\mathrm{MD}$ \\
\hline 38 & 458 & $\begin{array}{l}\text { Basser LS: Hemiplegia of early onset and the faculty of speech with special reference to the effects of hemispherectomy. } \\
\text { Brain 1962;85:427-460. }\end{array}$ & Func/Ana \\
\hline 39 & 453 & $\begin{array}{l}\text { Handforth A, DeGiorgio CM, Schachter SC, Uthman BM, Naritoku DK, Tecoma ES, Henry TR, Collins SD, Vaughn BV, } \\
\text { Gilmartin RC, Labar DR, Morris GL 3rd, Salinsky MC, Osorio I, Ristanovic RK, Labiner DM, Jones JC, Murphy JV, Ney } \\
\text { GC, Wheless JW: Vagus nerve stimulation therapy for partial-onset seizures: a randomized active-control trial. Neurology } \\
\text { 1998;51:48-55. }\end{array}$ & Epi \\
\hline 40 & 448 & $\begin{array}{l}\text { Penfield W, Welch K: The supplementary motor area of the cerebral cortex; a clinical and experimental study. AMA Arch } \\
\text { Neurol Psychiatry 1951;66:289-317. }\end{array}$ & Func/Ana \\
\hline 41 & 445 & $\begin{array}{l}\text { Hosobuchi Y, Adams JE, Linchitz R: Pain relief by electrical stimulation of the central gray matter in humans and its reversal } \\
\text { by naloxone. Science 1977;197:183-186. }\end{array}$ & Pain \\
\hline 42 & 443 & $\begin{array}{l}\text { Piccini P, Brooks DJ, Björklund A, Gunn RN, Grasby PM, Rimoldi O, Brundin P, Hagell P, Rehncrona S, Widner H, } \\
\text { Lindvall O: Dopamine release from nigral transplants visualized in vivo in a Parkinson's patient. Nat Neurosci 1999;2:1137- } \\
1140 .\end{array}$ & $\mathrm{MD}$ \\
\hline 43 & 443 & $\begin{array}{l}\text { Lunsford LD, Kondziolka D, Flickinger JC, Bissonette DJ, Jungreis CA, Maitz AH, Horton JA, Coffey RJ: Stereotactic } \\
\text { radiosurgery for arteriovenous malformations of the brain. J Neurosurg 1991;75:512-524. }\end{array}$ & Radio \\
\hline 44 & 440 & Engel J Jr: Surgery for seizures. N Engl J Med 1996;334:647-652. & Epi \\
\hline
\end{tabular}


Table 2 (continued)

\begin{tabular}{|c|c|c|c|}
\hline Rank & Citations & Paper & Category \\
\hline 45 & 438 & $\begin{array}{l}\text { Benabid AL, Pollak P, Louveau A, Henry S, de Rougemont J: Combined (thalamotomy and stimulation) stereotactic surgery } \\
\text { of the VIM thalamic nucleus for bilateral Parkinson disease. Appl Neurophysiol 1987;50:344-346. }\end{array}$ & $\mathrm{MD}$ \\
\hline 46 & 431 & $\begin{array}{l}\text { Kumar R, Lozano AM, Kim YJ, Hutchison WD, Sime E, Halket E, Lang AE: Double-blind evaluation of subthalamic nucleus } \\
\text { deep brain stimulation in advanced Parkinson's disease. Neurology 1998;51:850-855. }\end{array}$ & $\mathrm{MD}$ \\
\hline 47 & 431 & $\begin{array}{l}\text { Blomgren H, Lax I, Näslund I, Svanström R: Stereotactic high dose fraction radiation therapy of extracranial tumors using } \\
\text { an accelerator. Clinical experience of the first thirty-one patients. Acta Oncol 1995;34:861-870. }\end{array}$ & Radio \\
\hline 48 & 430 & $\begin{array}{l}\text { Krack P, Pollak P, Limousin P, Hoffmann D, Xie J, Benazzouz A, Benabid AL: Subthalamic nucleus or internal pallidal } \\
\text { stimulation in young onset Parkinson's disease. Brain 1998;121:451-457. }\end{array}$ & $\mathrm{MD}$ \\
\hline 49 & 430 & $\begin{array}{l}\text { Rodriguez-Oroz MC, Obeso JA, Lang AE, Houeto JL, Pollak P, Rehncrona S, Kulisevsky J, Albanese A, Volkmann J, Hariz } \\
\text { MI, Quinn NP, Speelman JD, Guridi J, Zamarbide I, Gironell A, Molet J, Pascual-Sedano B, Pidoux B, Bonnet AM, Agid Y, } \\
\text { Xie J, Benabid AL, Lozano AM, Saint-Cyr J, Romito L, Contarino MF, Scerrati M, Fraix V, Van Blercom N: Bilateral deep } \\
\text { brain stimulation in Parkinson's disease: a multicentre study with } 4 \text { years follow-up. Brain 2005;128:2240-2249. }\end{array}$ & MD \\
\hline 50 & 423 & $\begin{array}{l}\text { McLaughlin MR, Jannetta PJ, Clyde BL, Subach BR, Comey CH, Resnick DK: Microvascular decompression of cranial } \\
\text { nerves: lessons learned after 4,400 operations. J Neurosurg 1999;90:1-8. }\end{array}$ & Pain \\
\hline 51 & 417 & $\begin{array}{l}\text { Freed CR, Breeze RE, Rosenberg NL, Schneck SA, Kriek E, Qi JX, Lone T, Zhang YB, Snyder JA, Wells TH, et al: Survival of } \\
\text { implanted fetal dopamine cells and neurologic improvement } 12 \text { to } 46 \text { months after transplantation for Parkinson's disease. } \\
\text { N Engl J Med 1992;327:1549-1555. }\end{array}$ & $\mathrm{MD}$ \\
\hline 52 & 413 & $\begin{array}{l}\text { Lutz W, Winston KR, Maleki N: A system for stereotactic radiosurgery with a linear accelerator. Int J Radiat Oncol Biol } \\
\text { Phys 1988;14:373-381. }\end{array}$ & Tech \\
\hline 53 & 411 & $\begin{array}{l}\text { Backlund EO, Granberg PO, Hamberger B, Knutsson E, Mårtensson A, Sedvall G, Seiger A, Olson L: Transplantation of } \\
\text { adrenal medullary tissue to striatum in parkinsonism. First clinical trials. J Neurosurg 1985;62:169-173. }\end{array}$ & $\mathrm{MD}$ \\
\hline 54 & 408 & $\begin{array}{l}\text { Lozano AM, Lang AE, Galvez-Jimenez N, Miyasaki J, Duff J, Hutchinson WD, Dostrovsky JO: Effect of GPi pallidotomy on } \\
\text { motor function in Parkinson's disease. Lancet 1995;346:1383-1387. }\end{array}$ & $\mathrm{MD}$ \\
\hline 55 & 406 & $\begin{array}{l}\text { Jannetta PJ, Abbasy M, Maroon JC, Ramos FM, Albin MS: Etiology and definitive microsurgical treatment of hemifacial } \\
\text { spasm. Operative techniques and results in } 47 \text { patients. J Neurosurg 1977;47:321-328. }\end{array}$ & Pain \\
\hline 56 & 405 & Donoghue JP: Connecting cortex to machines: recent advances in brain interfaces. Nat Neurosci 2002;5(suppl):1085-1088. & Tech \\
\hline 57 & 404 & $\begin{array}{l}\text { Marsden CD, Obeso JA: The functions of the basal ganglia and the paradox of stereotaxic surgery in Parkinson's disease. } \\
\text { Brain 1994;117(Pt 4):877-897. }\end{array}$ & Func/An \\
\hline 58 & 403 & $\begin{array}{l}\text { Baron MS, Vitek JL, Bakay RA, Green J, Kaneoke Y, Hashimoto T, Turner RS, Woodard JL, Cole SA, McDonald WM, } \\
\text { DeLong MR: Treatment of advanced Parkinson’s disease by posterior GPi pallidotomy: 1-year results of a pilot study. } \\
\text { Ann Neurol 1996;40:355-366. }\end{array}$ & MD \\
\hline 59 & 401 & $\begin{array}{l}\text { Sweet WH, Wepsic JG: Controlled thermocoagulation of trigeminal ganglion and rootlets for differential destruction of pain } \\
\text { fibers. 1. Trigeminal neuralgia. J Neurosurg 1974;40:143-156. }\end{array}$ & Pain \\
\hline 60 & 401 & $\begin{array}{l}\text { Madrazo I, Drucker-Colín R, Díaz V, Martínez-Mata J, Torres C, Becerril JJ: Open microsurgical autograft of adrenal } \\
\text { medulla to the right caudate nucleus in two patients with intractable Parkinson's disease. N Engl J Med 1987;316:831-834. }\end{array}$ & MD \\
\hline 61 & 400 & $\begin{array}{l}\text { Auchter RM, Lamond JP, Alexander E, Buatti JM, Chappell R, Friedman WA, Kinsella TJ, Levin AB, Noyes WR, Schultz CJ, } \\
\text { Loeffler JS, Mehta MP: A multiinstitutional outcome and prognostic factor analysis of radiosurgery for resectable single } \\
\text { brain metastasis. Int J Radiat Oncol Biol Phys 1996;35:27-35. }\end{array}$ & Radio \\
\hline
\end{tabular}

Papers marked with an asterisk have had more than 100 citations per year since the year of their publication (until November 2011).

Func/Ana = Functional/anatomic study; MD = movement disorder study; Tech = technology study; Psych = psychiatry study; Epi = epilepsy study; Radio = radiosurgery study; Pain = pain study.

Besides the functional/anatomy category, the pain group had the largest representation prior to 1980 , with 6 papers in that era. Five (41.7\%) of the top 100 papers, of which 4 were citation classics, dealt with trigeminal or facial pain, while $4(33.3 \%)$ dealt with spinal cord stimulation.

\section{Psychiatry}

There were 2 publications dealing with psychiatric neurosurgery in the top 100, of which 1 can be designated a citation classic. Interestingly, both papers dealt with stimulation, either vagal nerve or deep brain, and both 


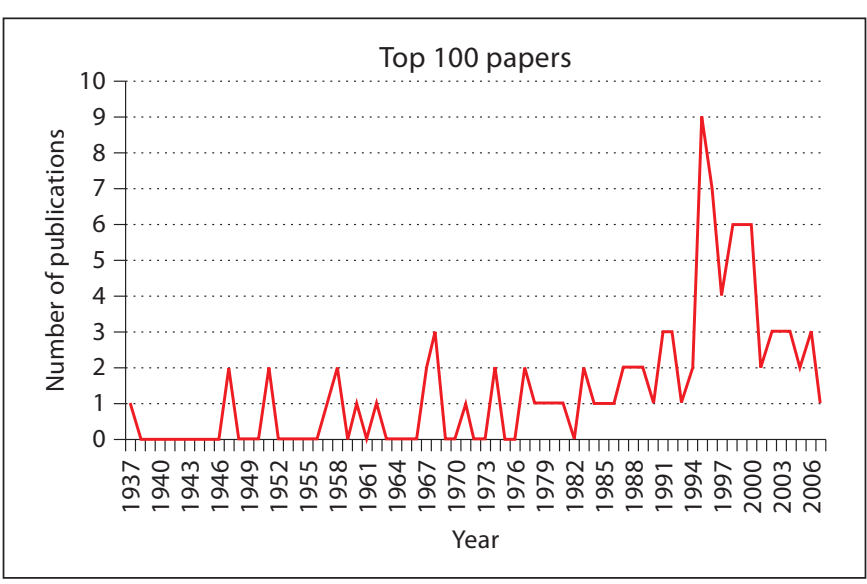

Fig. 1. The top 100 papers over time (citations per year).

were related to major depressive disorder. There were no papers dealing with ablative psychiatric surgery on the list, despite its relatively long history in the realm of functional neurosurgery.

\section{Epilepsy}

There were 3 publications in the top 100 that dealt primarily with epilepsy, and all 3 had over 400 citations. Two papers evaluated a therapy (vagal nerve stimulation and temporal lobectomy), and the third was a prominent and highly cited commentary on surgery for seizures. Of note, these papers dealt exclusively with the treatment of seizures with surgery and so were included in a distinct category. Several publications in the functional/anatomic category also involved patients with epilepsy who were tested intraand postoperatively in order to highlight the functional impact observed during and after seizure surgery. We distinguished these two categories by the primary intent of the articles rather than by the subject population per se.

\section{Radiosurgery}

For this category, we included all clinical articles using any form of radiosurgery, including Gamma Knife and linear accelerator. As such, the technological advances, most notably Leksell's 1951 paper, were not included here, but instead in the technology category. There were 13 clinical radiosurgery papers in the top 100, of which 7 were citation classics. Among these 13, 10 dealt with oncologic applications and 3 with arteriovenous malformations (the figures were 6 and 1, respectively, for citation classics). All of the citation classics in the clinical radiosurgery category were published after 1990.

Highly Cited Works in Functional Neurosurgery
Table 3. Journals containing 2 or more citation classics

$\begin{array}{lr}\text { NEJM } & 11 \\ \text { Journal of Neurosurgery } & 9 \\ \text { Brain } & 5 \\ \text { International Journal of Radiation Oncology, Biology, Physics } & 4 \\ \text { The Lancet } & 4 \\ \text { Annals of Neurology } & 4 \\ \text { Archives of Neurology and Psychiatry } & 2 \\ \text { Nature Neuroscience } & 2 \\ \text { Neuropsychologia } & 2 \\ \text { Neurology } & 2 \\ \end{array}$

Table 4. Categories of articles

\begin{tabular}{lcc}
\hline Category & Top 100 & $\begin{array}{l}\text { Citation } \\
\text { classics }\end{array}$ \\
\hline Epilepsy & 3 & 3 \\
Functional/anatomy & 27 & 13 \\
Movement disorders & 31 & 22 \\
Pain & 12 & 8 \\
Psychiatry & 2 & 1 \\
Radiosurgery & 13 & 7 \\
Technology & 12 & 7 \\
\hline Total & 100 & 61 \\
\hline
\end{tabular}

\section{Discussion}

We identified the top 100 most highly cited papers in the functional neurosurgery literature, of which 61 publications can be designated as citation classics.

\section{Trends over Time}

Convention would dictate that older publications, by virtue of having more years to accumulate citations, would necessarily be overrepresented in the top 100 and citation classic lists. However, this is not typically the case. As is illustrated in figure 1, there was a clear crescendo in highly cited works per year until the mid1990's, at which point the rate declined. This is likely due to two factors. First, the 1990's were particularly active years in functional neurosurgery, marked most significantly by the success of deep brain stimulation clinical trials. Second, the ' 90 's peak' may be a fundamental feature of contemporary research with a combination of not viewing as necessary the referencing of older publications that established basic principles but have since been replicated and newer publications that have not had time to

Stereotact Funct Neurosurg 2012;90:201-209 
Table 5. Number of citation classics by epoch in each category

\begin{tabular}{|c|c|c|c|c|c|c|c|c|}
\hline & 1930-1939 & 1940-1949 & 1950-1959 & 1960-1969 & 1970-1979 & $1980-1989$ & 1990-1999 & 2000-2009 \\
\hline Epilepsy & & & & & & & 2 & 1 \\
\hline Functional/anatomy & 1 & & 4 & 3 & 1 & 3 & 1 & \\
\hline Movement disorders & & & & & & 3 & 13 & 6 \\
\hline Pain & & & & 2 & 4 & & 2 & \\
\hline Psychiatry & & & & & & & & 1 \\
\hline Radiosurgery & & & & & & & 6 & 1 \\
\hline Technology & & 1 & 1 & & & 2 & & 3 \\
\hline
\end{tabular}

establish themselves as citation classics. Indeed we noted a similar '90's peak' in previous analyses that examined the citation classics in the major depression field [7]. It should be noted, however, that among the citation classics, 3/5 papers with over 1,000 citations were published in 1971 or before.

Trends of categories over time are particularly informative as these provide insights into the fluctuations of research interests over the years (table 5). For example, functional/anatomic studies, where cranial surgery was used as a laboratory of sorts to study the response to either electrical stimulation or cortical resection, were more common prior to 1970 than after. For example, Dr. Brenda Milner, whose practice grew primarily out of such anatomic investigations following cortical resections, has 7 publications in the top 100, including numbers 1 and 2 . It is also interesting to note, although not entirely surprising as this likely grew out of an increasing sophistication in trial design, that the clinical epilepsy papers on the citation classic list were all published after 1990.

In general, as shown in table 5 , there is a clustering of citation classics after 1980 , with $71 \%$ published after that year. Papers in the movement disorder category accounted for $50 \%$ of these, indicating that this field, and particularly PD research, dominated the functional neurosurgery research for the last 30 years.

\section{Absolute Number versus Velocity}

Whereas the absolute number of citations may provide an indication of where the field has been and is currently at, the velocity of accumulating citations, or the citations per year since publication, can provide an indication of where the field is going. Among the 61 citation classics, for example, only 4 had more than 100 citations per year since the date of their publication (until November 2011) (asterisks in table 2). These publications deal with brainmachine interface technology [12], deep brain stimulation for depression [13], deep brain stimulation for PD
[14], and temporal lobectomy for epilepsy [15]. There can be several reasons for the relative success and impact of these publications, not least of which is their significant overlap with other disciplines, which are substantially larger with a corresponding large literature, such as psychiatry and neurology. The velocity of growth of individual categories is also informative, and here, radiosurgery has made substantial strides, with 7 citation classics in the last 20 years, second only to movement disorders.

\section{Journals}

The 61 citation classics were published in 25 different journals, with 11 journals publishing at least 1 citation classic in the functional neurosurgery field. When the list is expanded to the top 100, 37 journals are included in the list, of which 14 have published 2 or more top 100 papers. Stereotactic and Functional Neurosurgery, the flagship publication of the functional neurosurgery field, has published 1 citation classic. As with other disciplines, such as $\mathrm{PD}$ and major depression, citation classics in functional neurosurgery tend to cluster in broadly applicable, typically higher impact publications, such as the New England Journal of Medicine and Brain. Again, as with citation velocity, this is largely a function of the wide applicability of research in functional neurosurgery, which is often easily relevant to neurologists, psychiatrists, neurophysiologists, other neuroscientists and, in some instances, to general practitioners.

\section{Limitations}

Studies such as this have several real and theoretical limitations. Most important is the possibility that our search strategy did not truly identify all the citation classics in functional neurosurgery. This may be a function of the search terms we used, although we attempted to be as inclusive as possible, or of the inclusion criteria we used to define relevant papers, although we attempted to keep these relatively broad. Nevertheless, there remains the 
possibility that there are highly cited papers relevant to the field of functional neurosurgery that were not included in the list. The list presented is a 'snapshot' in time that literally changes on a week-to-week basis, as the literature evolves. Citation classics will remain classics, but the constitution of the list and the relative 'rank' of publications are both dynamic and subject to constant change. In some ways, the citation classic and top 100 lists are saddled by the inherent obstacles of the functional neurosurgery field itself, which is quite broad and expansive. For example, publications in disciplines that are very active, popular and large will be more widely read and cited than those in fields that are highly specialized and small.

The optimal search algorithm and database are also a matter of debate as each will have unique advantages and disadvantages. Briefly, although discussed in a previous publication, Google Scholar's less restrictive criteria for journal archiving, its broad scope and the fact that it is publicly available and free influenced our decision to use it as the primary access point to the biomedical literature [7]. The relative merits of Google Scholar and our search software Publish or Perish versus other scholarly databases such as ISI Web of Science remain debatable and are largely subject to user preference and objective (for example, see [8] for an alternative strategy). Our aim was not to compare the results between databases, but to use a single database consistently to answer our research question. An additional limitation stems from our preferred means of categorization of retrieved results. For example, we decided to cluster functional investigations following cortical resection in epilepsy in a unique category rather than include these in the epilepsy category. These decisions were made according to the general theme and intent of the publication and to facilitate an analysis of trends over time. Nevertheless, they are individual preferences that are subject to debate (and controversy).

Ultimately, every aspect of the study described here, from the methodology to the results, is a matter of academic debate. We argue that, for such studies, debate is not only healthy but should be encouraged, so that by working as a community, a clearer picture can emerge of the work in the field that is truly influential and important.

\section{Conclusions}

We have attempted to identify the top 100 works and the citation classics in the functional neurosurgery field using citation indices as a proxy for their impact. Functional neurosurgery is a broad and rapidly growing field with the potential to influence the management of diseases across many disciplines. The publications highlighted in this paper represent particularly important contributions to the field and provide residents, beginner and experienced surgeons with a snapshot in time of the 'must-know' works in the field. The list is also an education in where our field has been as a whole and where it is currently at, and provides us with clues about where it is going next.

\section{References}

1 Garfield E: What is a citation classic? http:// garfield.library.upenn.edu/classics.html (accessed December 26, 2010).

$\checkmark 2$ Garfield E: 100 citation classics from the Journal of the American Medical Association. JAMA 1987;257:52.

3 Brandt JS, Downing AC, Howard DL, Kofinas JD, Chasen ST: Citation classics in obstetrics and gynecology: the 100 most frequently cited journal articles in the last 50 years. Am J Obstet Gynecol 2010;203:355.e1-355.e7.

4 Ohba N, Nakao K: The 101 most frequently cited articles in ophthalmology journals from 1850 to 1949. Arch Ophthalmol 2010; 128:1610-1617.

5 Ponce FA, Lozano AM: The most cited works in Parkinson's disease. Mov Disord 2011;26: 380-390.

6 Ponce FA, Lozano AM: Highly cited works in neurosurgery. Part II: the citation classics. J Neurosurg 2010;112:233-246.
7 Lipsman N, Lozano AM: The most cited works in major depression: the 'Citation classics'. J Affect Disord 2011;134:39-44.

8 Hung KC, Lan SJ, Liu JT: Global trend in articles related to stereotactic published in science citation index-expanded. Br J Neurosurg 2011, E-pub ahead of print.

$\checkmark 9$ Kondziolka D: Citation measures in stereotactic radiosurgery: publication across a discipline. Stereotact Funct Neurosurg 2011;89: 56-61.

10 Harzing AW: Publish or Perish, version 2.8.3644. Available at: http://www.harzing. com/pop.htm\#cite (accessed December 15, 2010).

11 Penfield W, Boldrey E: Somatic motor and sensory representation in the cerebral cortex of man as studied by electrical stimulation. Brain 1937;60:389-443.

12 Hochberg LR, Serruya MD, Friehs GM, Mukand JA, Saleh M, Caplan AH, Branner A,
Chen D, Penn RD, Donoghue JP: Neuronal ensemble control of prosthetic devices by a human with tetraplegia. Nature 2006;442: 164-171.

13 Mayberg HS, Lozano AM, Voon V, McNeely HE, Seminowicz D, Hamani C, Schwalb JM, Kennedy SH: Deep brain stimulation for treatment-resistant depression. Neuron 2005;45:651-660.

14 Krack P, Batir A, Van Blercom N, Chabardes S, Fraix V, Ardouin C, Koudsie A, Limousin PD, Benazzouz A, LeBas JF, Benabid AL, Pollak P: Five-year follow-up of bilateral stimulation of the subthalamic nucleus in advanced Parkinson's disease. N Engl J Med 2003;349:1925-1934.

15 Wiebe S, Blume WT, Girvin JP, Eliasziw M, Effectiveness and Efficiency of Surgery for Temporal Lobe Epilepsy Study Group: A randomized, controlled trial of surgery for temporallobe epilepsy. N Engl J Med 2001;345:311-318. 